\title{
E3 SUMO-Protein Ligase EGR2
}

National Cancer Institute

\section{Source}

National Cancer Institute. E3 SUMO-Protein Ligase EGR2. NCI Thesaurus. Code C131314.

E3 SUMO-protein ligase EGR2 (476 aa, $\sim 50 \mathrm{kDa}$ ) is encoded by the human EGR2 gene.

This protein plays a role in both protein sumoylation and sequence-specific DNA binding. 